\title{
Peran Gereja dalam Pembangunan Karakter sebagai Bentuk Tanggung Jawab Membangun Bangsa
}

\author{
S. Henderina A. Pello ${ }^{1}$, Philipus Sunardi ${ }^{2}$, Junius Nayoan ${ }^{3}$ \\ ${ }^{1,2,3}$ Sekolah Tinggi Teologia Ekumene, Jakarta \\ Correspondence: ririn@sttekumene.ac.id
}

\begin{abstract}
The purpose of character building is basically to build a nation's generation that grows and develops with Pancasila values, noble values, customs, and religion. Building the nation's next generation of character should be the responsibility of all parties, be it, families, schools, and churches. This certainly requires a responsibility that is not easy, so a strong commitment is needed to build it. The church is an important forum for character building in the life of the nation and state. Character development in particular is closely related to the affirmation of identity. This character building is closely related to Christian values as an instrument to achieve this goal. From this point of view, this study was developed to provide a reference for how the church is involved and plays an active role in building the nation through character building in accordance with the truth of God.
\end{abstract}

Keywords: church; character building; nation development

Abstrak: Tujuan pembangunan karakter pada dasarnya adalah untuk membentuk generasi bangsa yang tumbuh dan berkembang dengan nilai-nilai pancasila, nilai luhur, adat, dan agama. Membangun generasi penerus bangsa yang berkarakter seyogianya merupakan tanggung jawab semua pihak baik itu keluarga, sekolah maupun gereja. Hal ini tentu membutuhkan tanggung jawab yang tidak mudah, sehingga diperlukan komitmen yang kuat untuk membangunnya. Gereja menjadi wadah penting dalam pembangunan karakter di tengah kehidupan berbangsa dan bernegara. Pembangunan karakter secara khusus berhubungan erat dengan peneguhan jati diri. Pembangunan karakter ini berhubungan erat dengan nilai-nilai kekristenan sebagai instrumen untuk mencapai tujuan tersebut. Dari sudut pandang inilah kajian ini dikembangkan untuk memberikan acuan bagaimana gereja terlibat dan berperan aktif dalam membangun bangsa melalui pembangunan karakter yang sesuai dengan kebenaran firman Tuhan.

Kata kunci: gereja; pembangunan karakter; pembangunan bangsa

\section{Pendahuluan}

Kata karakter berasal dari bahasa Yunani charassein, yang berarti to engrave (melukis, menggambar), seperti orang yang melukis kertas, memahat batu atau metal. Berakar dari pengertian yang seperti itu, karakter kemudian diartikan sebagai tanda atau ciri yang khusus, dan karenanya melahirkan suatu pandangan bahwa karakter adalah 'pola perilaku yang bersifat individual, keadaan moral seseorang'. Setelah melewati tahap anak-anak, seseorang memiliki karakter, cara yang dapat diramalkan bahwa karakter seseorang berkaitan dengan perilaku yang ada di sekitar dirinya (Ryan, Kevin \& Karen E. Bohlin, 1999).

Karakter merupakan persoalan sangat penting dalam hidup manusia baik bagi kehidupan individu maupun sosial bahkan bangsa. Seperti yang dikatakan Willy Susilo bahwa perihal 
karakter menjadi topik pembicaraan yang tidak pernah usang. Topik ini diperbincangkan di banyak kalangan, mulai dari orang awam, ilmuwan, bahkan negarawan, bahwa karakter adalah suatu hal yang sangat penting bagi kemajuan manusia, secara individual maupun suatu bangsa (Susilo, 2013). Thomas Lickona seorang pakar Pendidikan Karakter dari Amerika Serikat menyatakan bahwa ukuran kemajuan suatu negara bukanlah besarnya pendapatan nasional, kemajuan teknologi, atau kekuatan militernya, melainkan karakter penduduknya (Borba, 2008).

Karakter yang baik berkaitan dengan mengetahui yang baik (knowing the good), mencintai yang baik (loving the good), dan melakukan yang baik (acting the good). Pengetahun yang baik berarti dapat memahami dan membedakan antara yang baik dan yang buruk. Mengetahui yang baik berarti mengembangkan kemampuan untuk menyimpulkan atau meringkaskan suatu keadaan, memilih sesuatu yang baik untuk dilakukan, dan kemudian melakukannya. Aristoteles menyebutnya dengan practical wisdom (kebijakan praktis). Memiliki kebijakan praktis berarti mengetahui keadaan apa yang diperlukan dan yang baik dalam hidup.

Selanjutnya Aristoteles mendefinisikan karakter yang baik sebagai tingkah laku yang benar. Tingkah laku yang benar dalam hubungannya dengan orang lain dan juga dengan diri sendiri. Di pihak lain, karakter, dalam pandangan filosof kontemporer adalah campuran atau perpaduan dari semua kebaikan yang berasal dari tradisi keagamaan, cerita, dan pendapat orang bijak, yang sampai kepada kita melalui sejarah. Seseorang dengan karakter terpuji dapat dibedakan dari yang lainnya (Lickona, 1991). Ciri khas setiap orang atau individu untuk hidup dan bekerja sama, baik dalam lingkungan keluarga, masyarakat, bangsa dan negara.

Membangun karakter berarti membangun suatu pola dari sikap yang hendak didemonstrasikan dalam hubungan antara satu dengan lain. Sikap yang didemonstrasikan itu merupakan ciri khas moral atau etika Kristen. Gereja dan orang percaya harus menempatkan Kristus sebagai pusat kehidupan mereka, sehingga pembentukan karakter menghasilkan individu-individu yang militan di tengah kehidupan berbangsa dan bernegara. Karakter tidak cukup hanya dipelajari melalui banyaknya teori, tetapi harus sampai masuk ke dalam hati hingga menjadi energi penggerak untuk dilakukan. Tukidi dalam pembahasannya mengatakan bahwa keberhasilan membangun karakter bangsa menjadi penentu terhadap eksistensi bangsa di masa yang akan datang (Tukidi, 2011).

Artikel ini ingin mengusung peran gereja dalam pembangunan karakter anak bangsa sebagai bentuk tanggung jawabnya terhadap negara.

\section{Metode Penelitian}

Adapun metode ysng digunakan dalam penelitian ini adalah metode kualitatif yaitu metode penelitian kepustakaan yang berfokus pada pembahasan mengenai Peran Gereja Dalam Pembangunan Karakter Sebagai Bentuk Tanggung Jawab Membangun Bangsa. Menurut Supriadi studi kepustakaan adalah serangkaian pengumpulan data dengan membaca, menulis, serta mengolah bahan penelitian (Supriadi, 2016).

\section{Pembahasan}

Dalam pengajaranNya, Yesus sering menekankan karakter kepada para murid. Karakter meliputi: integritas, kemurnian moral dan hubungan dengan Kristus. Unsur karakter Kristen sangat penting sehingga Yesus mengajarkannya kepada para murid (J.C, 2001). Karakter diartikan sebagai nilai yang membangun pribadi seseorang yang terbentuk karena pengaruh hereditas (bawaan) serta pengaruh lingkungan. Kebiasaan ini kemudian menghasilkan kepribadian yang unik yang membedakan seseorang dari orang lain yang dapat dilihat dari 
kehidupan sehari-hari. Oleh sebab itu, karakter tidak dapat diwariskan. Karakter Kristus dapat terbentuk melalui perjumpaan dengan Allah. Hal itu hanya mungkin terjadi jika seseorang belajar firman Allah, merenungkan firman Allah dan menerapkannya.

Karakter menurut Alkitab adalah sikap hidup takut akan Allah dan berjuang hanya untuk menyenangkan Tuhan, tidak peduli bagaimana perasaaan kita, atau apa yang mungkin akan dikatakan atau dilakukan orang lain. Membangun karakter ialah "mengukir nilai/prinsip kebenaran Allah atau mengoreskan/menandai diri dengan praktik hidup benar berdasarkan firman Tuhan.

Secara sederhana karakter adalah: "Melakukan apa yang benar karena hal itu benar. Orang yang berkarakter adalah orang yang melakukan apa yang benar karena alasan yang benar." Karakter adalah tentang siapa kita, atau ada yang mengatakan tentang diri kita terbuat dari apa. Karakter-Karakter yang baik yang harus dihidupi menurut firman Tuhan adalah kasih, kesabaran, kemurahan hati, kebaikan, kesetiaan, kelemahlembutan dan penguasaan diri (Galatia 5:22) (LAI, Alkitab Terjemahan Baru, 2012).

Firman Tuhan dengan jelas mengajarkan kepada orang percaya untuk hidup di dalam kasih. Kasih bukan hanya kepada orang yang dikenal tetapi kepada semua orang dengan berbagai perbedaan yang ada. Dalam kehidupan berbangsapun, kasih menjadi landasan utama untuk membangun persatuan dan kesatuan. Dalam perumpamaan tentang orang Samaria yang murah hati (Lukas 10:25-37), Yesus mau menegaskan bahwa pengajaran tentang sikap moral atau karakter yang baik harus dibangun oleh setiap orang percaya. Perumpamaan tersebut merupakan gambaran kasih yang besar. Tuhan Yesus menempatkan orang Samaria sebagai pemberi kasih yang besar tanpa pamrih bagi orang Yahudi yang sama dibenci juga oleh bangsa-Nya. Dengan membangun konsep belas kasihan, Tuhan Yesus menanggapi realitas kehidupan yang ditandai dengan berbagai pergumulan social yang ada (Suardana, 2015). Yesus melayani semua orang melampaui batasan keluarga, kerabat, suku, bangsa, budaya, agama atau batas apa pun lainnya. Belas kasihan merupakan kekuatan moral yang membebaskan seseorang dari belenggu pandangan sempit tentang sesame. Oleh karena itu, gereja harus hadir dan mengajarkan sifat/karakter kasih seperti yang Yesus ajarkan dan lakukan.

Di dalam Roma pasal 12:2, Rasul Paulus menekankan bahwa pembaharuan budi adalah kunci untuk mengetahui apa yang baik dan yang berkenan kepada Allah. Artinya bahwa seseorang harus terus mengalami pembaharuan pikiran/akal budi yang tentunya akan bermuara kepada perkenanan Allah. Pembaharuan budi ini tentu saja tidak serta merta diperoleh melalui Pendidikan ataupun pengetahuan akali, pembaharuan budi lebih kepada seberapa dalam seseorang mengalami perjumpaan dengan Tuhan. Hal ini menjadi salah satu tanggung jawab gereja, yakni membangun generasi-generasi penerus dalam pembaharuan budi/nilai-nilai kebaikan melalui perjumpaan dengan Tuhan.

Sikap/karakter lain yang Tuhan Yesus ajarkan adalah sikap toleransi. Dalam Lukas 9:5156, ketika sebuah desa Samaria menolak Tuhan Yesus (baik sebagai orang Yahudi maupun karena ajaran-Nya), la memarahi murid-murid-Nya yang ingin menghancurkan desa tersebut. Hal ini menunjukkan sikap Tuhan Yesus yang sangat "toleran" dan mengasihi bahkan terhadap orang-orang yang menolak-Nya. Dalam konteks kehidupan bersama di tengah masyarakat yang plural, gereja maupun orang percaya dipanggil untuk mengembangkan etika kehidupan bermasyarakat yang ditandai dengan sikap saling menerima dan menghormati dalam kasih tanpa mengorbankan orang lain. Gereja harus membangun orang percaya untuk mengembangkan sikap hidup toleransi atau tenggang rasa terhadap kepercayaan lain. 
Karakter penting lainnya yang diajarkan oleh Yesus adalah tentang ketaatan dan ketundukan kepada Pemerintah. Dalam perikop Markus 12:13-17, orang-orang Farisi dan Herodian bermaksud jahat, yaitu mereka ingin menjerat Yesus dengan suatu pertanyaan (ay. 13) tetapi maksud mereka diketahui oleh Yesus. Mereka berusaha menjebak Yesus, karena mereka tahu akan klaim dari Yesus sebagai Mesias. Dan dalam pemikiran mereka, seorang Mesias adalah orang yang membebaskan bangsa Israel dari penjajahan Romawi dan memulihkan Kerajaan Israel di dunia. Jadi, mereka berharap bahwa Yesus akan menjawab "tidak perlu membayar pajak kepada kaisar", agar mereka dapat menangkap Yesus dan menyerahkan-Nya kepada pemerintahan Romawi - karena menghasut rakyat untuk tidak membayar pajak. Namun, Yesus memberikan jawaban yang membuat mereka semua terkejut dan heran, ketika Yesus berkata "Berikanlah kepada Kaisar apa yang wajib kamu berikan kepada Kaisar dan kepada Allah apa yang wajib kamu berikan kepada Allah!" Dengan jawaban ini, maka mereka tidak mempunyai alasan untuk menangkap Yesus. Rasul Paulus menekankan hal yang sama dalam kitab Roma 13:1. Gereja harus berani mengajarkan sikap jujur dan taat/tunduk kepada pemerintah yang ada seperti yang telah Yesus ajarkan. Kata hupotasso diterjemahkan oleh LAI sebagai "takluk" atau dalam kata Inggris to be subject (dalam terj. RSV) dan to submit (dalam terj. NEB). Artinya adalah tunduk atau menempatkan diri lebih rendah (Sutanto, Hermeneutik: Prinsip dan Metode Penafsiran Alkitab, 2019). Kata takluk menempatkan seseorang ber-ada di bawah kekuasaan pihak yang berkuasa. Dengan kata lain, seorang warga negara yang baik harus memberi penghormatan kepada pemerintah yang berkuasa dan mene-rima atau melakukan peraturan-peraturan yang dibuat pemerintah.

Dalam Yeremia 29:7, Allah juga memberi mandat kepada umat pilihanNya agar mereka dapat berperan aktif dalam kehidupan berbangsa dan bermegara dengan jalan mengusahakan kesejahteraan kota dan mendoakannya (Sulopo, 2019). Gereja dan orang percaya harus dapat berperan aktif dalam mengusahakan kesejahteraan bangsa dengan memberi pengaruh yang baik kepada orang lain.

Gereja yang telah dilimpahi anugerah Kristus penuh dengan kecakapan atau kemampuan untuk menciptakan kesempatan-kesempatan yang pada akhirnya mampu membangun sebuah kehidupan yang luhur, mulia, indah, harmonis, dan sejahtera. Setiap individu akan terbangun dalam nilai-nilai luhur dan mulia dari kebenaran-kebenaran Tuhan yang dikumandangkan melalui Firman Tuhan dan orang-orang percaya akan memberi pengaruh yang positif terhadap komunitas-komunitas dari berbagai profesi dan tingkatan kehidupan sehingga tercipta dan terbangun sebuah kehidupan berbangsa, bernegara, dan bermasyarakat yang semakin baik. (King, 2013).

\section{KESIMPULAN}

Landasan membangun karakter bangsa yang terfokus kepada membangun karakter umat sebagai komunitas mikro dalam Negara Kesatuan Republik Indonesia (komunitas makro), sebagai dasar untuk membangun Indonesia Jaya. Gereja memainkan peran penting dalam membentuk kepribadian atau karakter dari generasi penerus bangsa. Karena itu gereja harus terus menanamkan nilai-nilai (values) kebajikan (vitues) dan pola kehidupan yang sesuai dengan standard kebenaran firman Tuhan. Nilai-nilai kebaikan seperti belas kasih, empati, penguasaan diri, rasa hormat, toleransi, adil dan cinta tanah air, sebagai landasan untuk membangun karakter generasi penerus dan juga yang dapat memunculkan pribadi-pribadi yang berkarakter unggul. Orang yang berkarakter pasti tidak akan melakukan hal-hal yang diketahuinya salah, karena hal itu bertentangan dengan imannya dan juga suara hatinya yang 
telah diterangi oleh firman Tuhan. Gereja dipanggil dalam perannya sebagai garam dan terang dunia, supaya melalui pembaruan karakter, orang percaya dapat menjadi saksi Kristus yang memberikan pengaruh positif demi terciptanya keharmonisan dan kerukunan di tengah-tengah bangsa yang majemuk.

\section{REFERENSI}

Borba, M. (2008). Membangun Kecerdasan Moral. Jakarta: Gramedia.

J.C, W. (2001). Kepemimpinan Kristen Yang Mengubahkan. Yokyakarta: ANDI.

King, A. (2013, 4 15). Diambil kembali dari https://powerstatus.wordpress.com/2013/04/15/gereja-dalam-revitalisasi-kehidupanberbangsa-bernegara-dan-bermasyarakat/.

LAI. (2012). Alkitab Terjemahan Baru. Jakarta: LAI.

Lickona, T. (1991). Educating for Character: How Our School Can Teach Respect and Responsibility. New York: Bantam Book.

Ryan, Kevin \& Karen E. Bohlin. (1999). Building Character in Schools: Practical Ways to Bring Moral Instruction to Life. San Francisco: Wiley Imprint.

Suardana, I. M. (2015). Identitas Kristen Dalam Realitas Hidup Berbelaskasihan: Memaknai Kisah Orang Samaria yang Murah Hati. Jurnal Jaffray, 125.

Sulopo, E. (2019, 4 15). Diambil kembali dari https://sttin.id/peran-orang-kristen-dalamkehidupan-berbangsa/.

Supriadi. (2016). Community of Practioners: Solusi Alternatif Berbagai Pengetahuan antar Informasi dan Kearsipan (Vol. 2). -.

Susilo, W. (2013). Membangun Karakter Unggul. Yokyakarta: ANDI.

Sutanto, H. (2007). Hermeneutik: Prinsip dan Metode Penafsiran Alkitab. Malang: SAAT.

Tukidi (2011). Membangun Karakter Bangsa di Tengah-tengah Budaya Global. Jurnal 